\title{
ICT and Scientific Production at the Technical University of Cotopaxi, its visibility through a Latindex
}

\author{
Las TIC y la Producción Científica en la Universidad Técnica de \\ Cotopaxi, su visibilidad a través de la revista Latindex
}

\section{TIC e produção científica na Universidade Técnica de Cotopaxi, sua visibilidade através da revista Latindex}

\author{
Nancy E. Tapia-Gaibor ${ }^{\mathrm{I}}$ \\ nancyftapia@gmail.com \\ José M. Lalama-Aguirre II \\ joselalama@gmail.com \\ Santiago O. Sánchez-Andrade ${ }^{\text {III }}$ \\ santiandrade@gmail.com \\ Chistian R. Tapia-Gaibor ${ }^{\text {IV }}$ \\ chistiantapia@gmail.com \\ Vanessa P. Quishpe-Morocho v \\ vanequishpe@gmail.com \\ Patricia G. López-Fraga vI \\ pfraga@gmail.com

\footnotetext{
${ }^{\mathrm{I}}$ Docente, Universidad Central del Ecuador, Quito, Ecuador.

${ }^{\text {II }}$ Docente, Universidad Central del Ecuador, Quito, Ecuador.

III Docente, Universidad Central del Ecuador, Quito, Ecuador.

${ }^{\text {IV }}$ Docente, Universidad Central del Ecuador, Quito, Ecuador.

${ }^{\vee}$ Docente, Universidad Central del Ecuador, Quito, Ecuador.

${ }^{\mathrm{VI}}$ Docente, Universidad Central del Ecuador, Quito, Ecuador.
}

Recibido: 13 de enero de 2017 * Corregido: 20 de febrero de 2017 * Aceptado: 08 de junio de 2017 


\section{Abstract}

It is an increasingly eloquent challenge for higher education institutions, the index of scientific production is synonymous with quality, it is clear that Ibero-America is emerging in the generation of a scientific culture; however there are deficiencies to overcome in the budgetary and cultural subject.

Latindex in its eagerness to support the generation of science in these Latin American countries propitiates this system of information of which the Technical University of Cotopaxi is part from the year 2015. Now with projection to Open Journal System and other data bases, whose aim is the diffusion of knowledge.

These pathways and paths are fundamental for the development and advancement of science, our nations and our locality, sowing the seed of research in the digital age, where ICTs have revolutionized culture in the world, advancing with leaps its projection.

It is through scientific journals and with the contribution of research networks or scientific communities that knowledge has been blurred all over the planet, it is clear as a vector the computer technologies that provide an increasingly solid and efficient support for the management of the science. More when now is no problem information but the management and administration of it.

Keywords: Open Journal System; UTC; scientific journals. 


\section{Resumen}

Constituye para los centros de educación superior un desafío cada vez más elocuente para su visibilidad, es sinónimo de calidad los índices de producción científica, es claro que Iberoamérica estamos despuntando en la generación de una cultura científica; sin embargo hay deficiencias por superar en el tema presupuestario y cultural.

Latindex en su afán de apoyar la generación de ciencia en estos países de Iberoamérica propicia este sistema de información del cual la Universidad Técnica de Cotopaxi es parte desde el año 2015. Ahora con proyección a Open Journal System y otras bases de datos, cuyo fin es la difusión del conocimiento.

Estos caminos por recorridos y por recorrer son fundamentales para el desarrollo y avance de la ciencia, de nuestras naciones y de nuestra localidad, sembrando la semilla de la investigación en la era digital, dónde las TIC han revolucionado la cultura en el mundo, avanzando con pasos agigantados su proyección.

Es a través de las revistas científicas y con al aporte de las redes de investigación o comunidades científicas que el conocimiento se ha difuminado por todo el planeta, claro está como vector las tecnologías informáticas que brindan un soporte cada vez más sólido y eficiente para la gestión de la ciencia. Más cuándo ahora ya no es problema la información sino la gestión y administración de ella.

Palabras Clave: Open Journal System; UTC; revistas científicas. 


\section{Introduction}

The Technical University of Cotopaxi is a public institution located in north central Ecuador, its philosophy is humanistic, with twenty-two years of service in higher education of Ecuador, has an indexed magazine in Latindex Catalog, so far accounts more than 51 articles published and 9 volumes. (Research, 2017)

The Scientific Production of the Technical University of Cotopaxi is characterized to be pertinent and concerned with problems related to the environment. To a great extent they are part of a generative research; is flexible and open to areas of knowledge that are taught in the Institution.

ICT on the other hand are attractive, motivating and complex, but there is a teaching sector that are not friendly with computers and they are missing a great opportunity to gain more experience and to contribute in the generation of knowledge, technological support and communication that provides ICT, in which the role of the teacher is transformed from being a mere transmitter to being the mediator, so that the students are the builders of knowledge themselves (Gisbert et al., 1997)

Scientific production is combined with ICT; since technologies favor significantly the diffusion of knowledge and the access of the information at great scales, it makes possible to optimize time and resources, it also contributes to be internationally visualized. (Pérez, 1998) "Computer technology, by providing every researcher with immediate access to global knowledge, providing sophisticated tools for data processing and control, facilitates the generation of new knowledge" ( Vargas M., 2005)

\footnotetext{
717 Vol. 3, núm. mon., agosto, 2017, pp. 714-733 Nancy E. Tapia-Gaibor; José M. Lalama-Aguirre; Santiago O. Sánchez-Andrade; Chistian R. TapiaGaibor; Vanessa P. Quishpe-Morocho; Patricia G. López-Fraga
} 
Scientific production is considered to be a materialized part of knowledge generated from a research process, it is more than a set of documents stored in an information institution. It is also considered an important tool for all academic and scientific activities of a researcher. (Piedra, 1997)

In addition, it serves to communicate the new contributions of science, starting back in the 90's and with the appearance of the Internet (Lombardo, 2013). It solves the multiple problems of information, accessibility, optimizing dimensions such as time and space.

Therefore, in an institution of higher education, scientific production is fundamental; its contributions are the creation of new theories, methods and research procedures; it is an important link since it constitutes to be part of a measurable element for the dissemination of results.(Spinak, 1996)

It is said that education is the engine of the development of people, then scientific production is the motor of the development of education. This catalog had helped to increase scientific production of this institution ant to achieve standards of quality. Therefore the absence of scientific production is the product of an incipient development in education that does not respond to the need of society in general, it inhibits the development of science.

In 2012, the current regulatory body CEACCES (Council for Evaluation, Accreditation and Quality Assurance in Higher Education) carried out the process of Categorization of all universities in Ecuador. UTC (Technical University of Cotopaxi) was placed as a university with category C. 


\begin{tabular}{|l|c|c|}
\hline \multicolumn{3}{|c|}{ Criteria Research } \\
\hline & $\begin{array}{c}\text { Research } \\
\text { planning }\end{array}$ & $\begin{array}{c}\text { Financial } \\
\text { resources }\end{array}$ \\
\hline CEAACES 2015 & 0 & 0 \\
\hline $\begin{array}{l}\text { CIFI-UTC-17- MARCH } \\
\text { 2017 }\end{array}$ & 0 & 0 \\
\hline CIFI-UTC-17- JULE 2017 & 0.35 & 0.35 \\
\hline $\begin{array}{l}\text { CIFI-UTC-17- OCTOBER } \\
\text { 2017 }\end{array}$ & 0.7 & 0.7 \\
\hline
\end{tabular}

Fuente: CIFI UTC, October

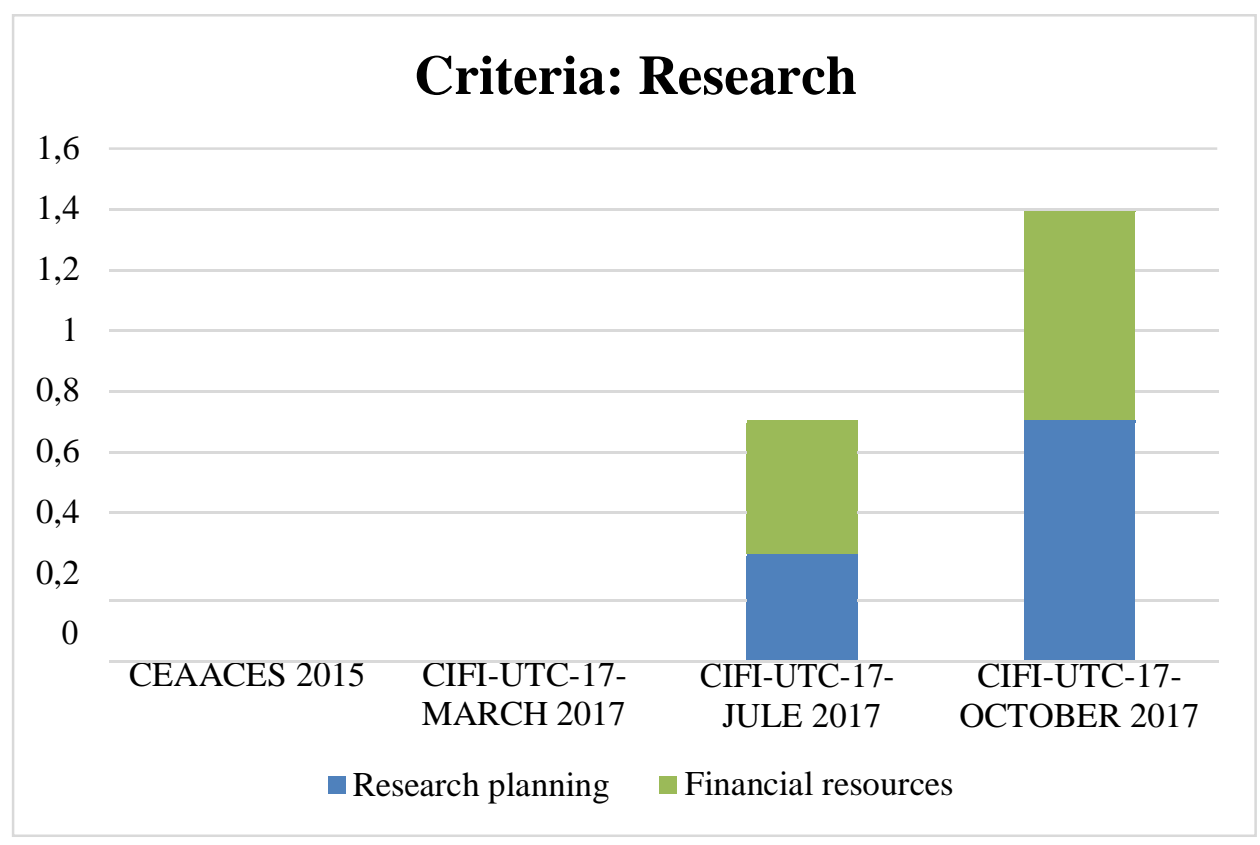


ICT and Scientific Production at the Technical University of Cotopaxi, its visibility through a Latindex

\begin{tabular}{|l|c|cc|}
\hline & \multicolumn{3}{|c|}{ Criteria: Research } \\
\hline & $\begin{array}{c}\text { Scientific } \\
\text { production }\end{array}$ & $\begin{array}{c}\text { Regional } \\
\text { production }\end{array}$ & $\begin{array}{c}\text { Books or chapters of } \\
\text { books revised by } \\
\text { couple }\end{array}$ \\
\hline CEAACES 2015 & 0.06 & 0.02 & 0.04 \\
\hline CIFI-UTC-17- MARCH 2017 & 0.06 & 0.02 & 0.04 \\
\hline CIFI-UTC-17- JULE 2017 & 0.07 & 0.54 & 0.09 \\
\hline CIFI-UTC-17- OCTOBER 2017 & 0.07 & 0.78 & 0.23 \\
\hline
\end{tabular}

Fuente: CIFI UTC, October 2001

\section{Criteria: Research}

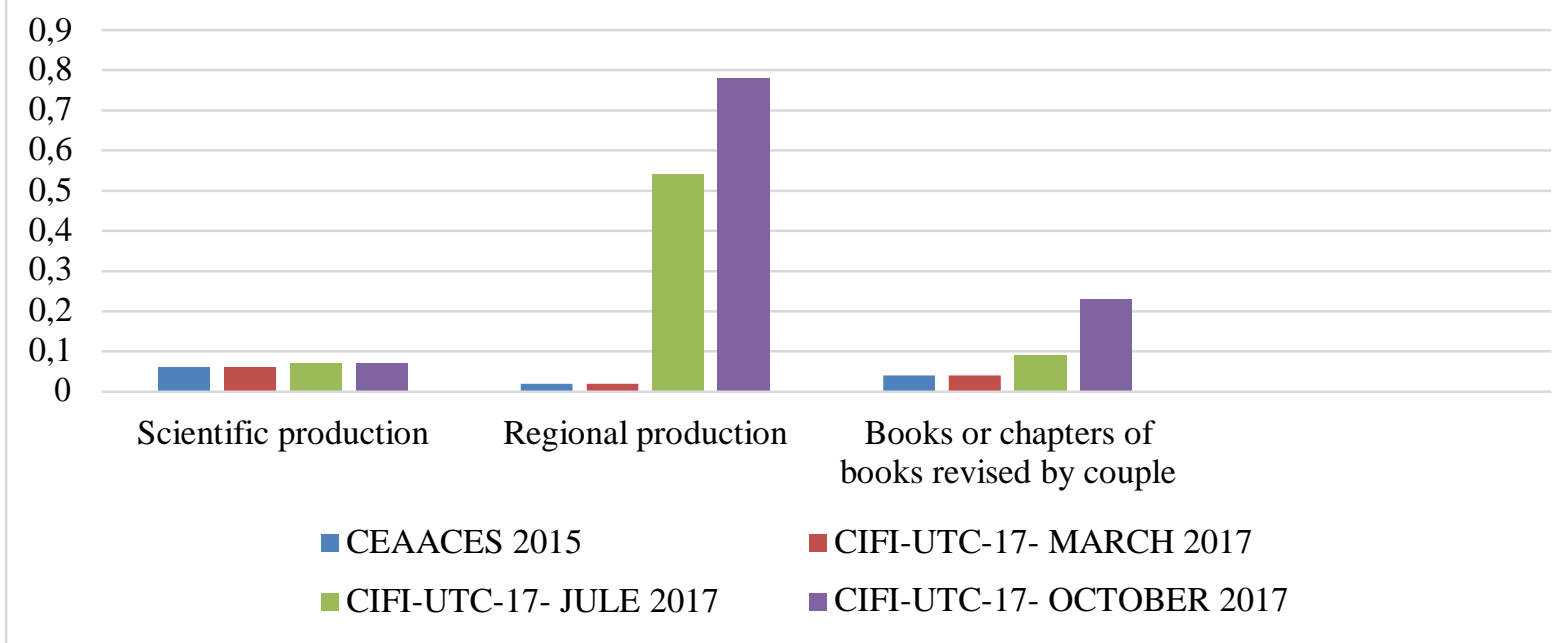


Research, as it is established by the Council of Evaluation Accreditation and Insurance of the Top Educational quality (CEAACES), is a substantive function of the universities and polytechnical schools that must be planned and be executed considering the institutional targets, assuring a structure and the availability of resources, which should make possible to reach increasing quality levels. In this sense, on having obtained in the investigation criterion deficient qualifications, one determines that the University did not achieve to articulate an investigation system sustainable, compromising seriously the growth of the scientific production and the proliferation of research projects articulated to lines and groups of investigation. That one owes to supposed administrative aberrations, like the absence of clarity in the handling of the funds that the Institution of Higher education (IHE) destines for this activity.

\begin{tabular}{|l|l|l|l|l|l|l|l|l|l|}
\hline \multicolumn{10}{|c|}{ SCIENTIFIC PRODUCTION UTC } \\
\hline \multicolumn{1}{|c|}{ YEARS } & $\mathbf{2 0 1 0}$ & $\mathbf{2 0 1 1}$ & $\mathbf{2 0 1 2}$ & $\mathbf{2 0 1 3}$ & $\mathbf{2 0 1 4}$ & $\mathbf{2 0 1 5}$ & $\mathbf{2 0 1 6}$ & $\mathbf{2 0 1 7}$ & TOTAL \\
\hline $\begin{array}{l}\text { SCIENTIFIC } \\
\text { ARTICLES }\end{array}$ & 0 & 1 & 1 & 0 & 21 & 39 & 64 & 70 & 196 \\
\hline BOOKS & 0 & 1 & 1 & 3 & 4 & 7 & 9 & 23 & 48 \\
\hline
\end{tabular}

Fuente: Research, UTC, 2017 


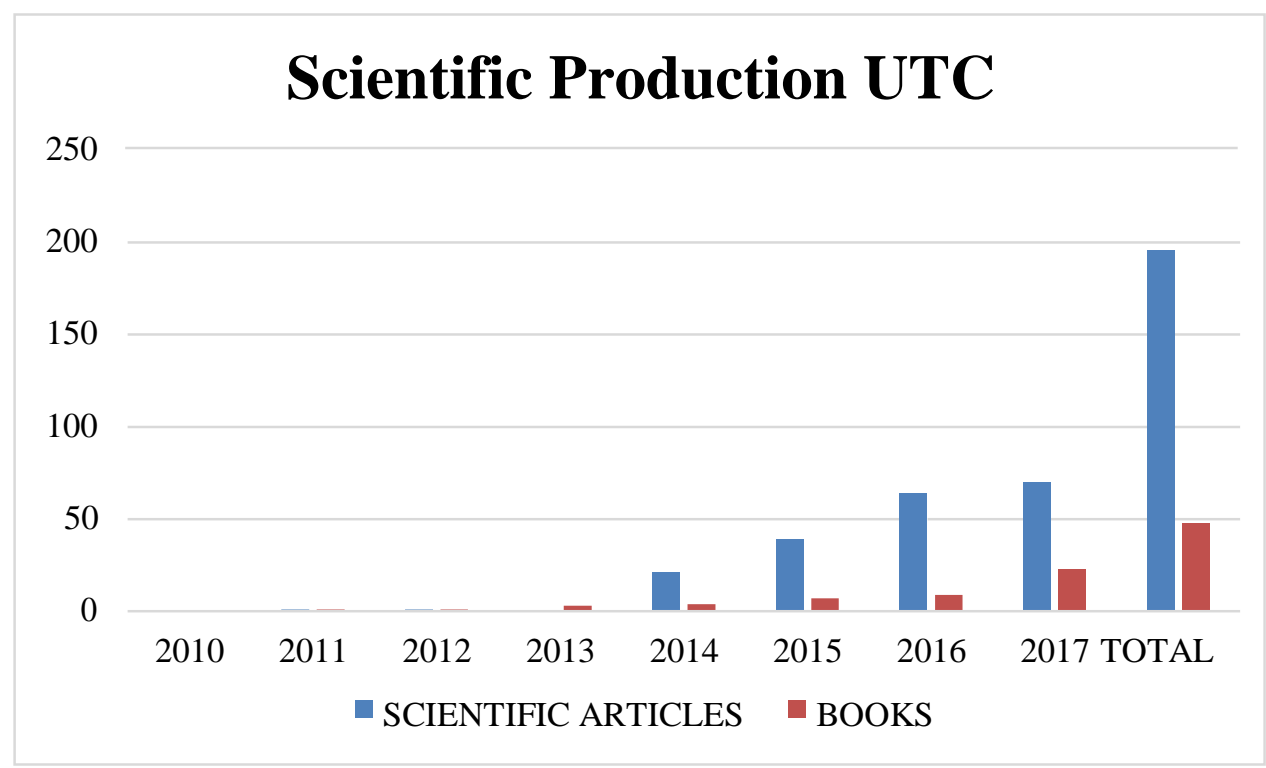

The scientific production that has been developed and disseminated in the last four years in the Technical University of Cotopaxi is mainly the production of books and scientific articles that cover the areas of factual knowledge, in agreement with the academic offer of the institution as well as the results of research projects and independent studies.

As a result of the quality and impact of publications, it is regrettably established that Latin American or Spanish journals are underrepresented in these databases, remaining in a vicious circle: "because they are not quoted they are not in the indexes of citation and as they are not in the indices are not quoted "(Aguado et al., 2003), reason why much of lost science is estimated.

With regard to funding in education, UNESCO considers it prudent to allocate $8 \%$ of each country's GDP for education. In Ecuador according to the report of the president says that in 2013 has invested 7.348 billion dollars in education, this is equivalent to $1.8 \%$ of GDP. However, it states that the expected result is not as the development in the quality of education, considers that $54 \%$ of the total budget of the HEI is allocated to administrative expenditure. (Citizen, 2013) 
Thus Latindex operates on the basis of regional cooperation, the online data system is in charge of the UNAM; Here is a detail of countries associated with their year of appointment in chronological order: 1997 Brazil, Cuba, Mexico, Venezuela; Argentina, Chile, Spain; 1999 Colombia, Portugal, Puerto Rico; 2001- Ecuador; 2002 - Costa Rica, Uruguay; 2003- Peru; 2004 Bolivia, 2005 - France, Panama, Dominican Republic, 2006 - Guatemala; 2009 - Nicaragua; 2010Honduras; 2011- El Salvador, Paraguay and 2014 South Korea. (Latindex, 2017)

As we have seen so far, this database has the fundamental purpose of integrating efforts in the production, registration and use of academic journals, as well as to reinforce the quality and impact of scientific journals; international scientific production and the generation of byproducts. In the case of Ecuador, the Senescyt (Secretary of Higher Education Science, Technology and Innovation) is its representative.

It is structured by Directory, Catalog, Online Magazines and Portals; the visualization is done through the electronic information system, it also provides access to the full texts of academic journals in digital newspapers, adhered to the open access movement and the computerized development uses OAI Harvester 2, based on the protocol OAI PHM

Through the indexed journals our teachers keep up to date and share their knowledge and experiences with their peers in the world. Students at all levels have access to the highest volume of quality information (Dávila, 2006). To do this, it is necessary to know how to process this information, the use of ICT and the necessary tools for searching, organizing and managing information. 
Then we can see how internationalization is becoming the main strategy through which universities face the challenge of redefining their research tasks within a changing context that gives their activities a new dynamic: globalization ( Gibbons, 2003).

The study by Quintanilla (2008) argues that the reason for the low production in Latin America is the little investment that varies between 0.1 and $0.6 \%$ of GDP. It also states that the main cause is the academic and university culture, the lack of technological infrastructure and the political - legal difficulties for its development.

\section{The Scientific Journals.}

At the beginning of the post-Gutenberg era, information producers and their institutions have the ability to publish and disseminate their work directly, without editorial intermediaries, and with smaller cost. ICT is one of the central axis of academic activity in promoting new ways for the production, preservation and dissemination of knowledge (Davila, 2006).

UNESCO classifies journals in the following categories: Primary Magazines of Information. The results of research and development work are published, with all their details to corroborate the validity of the author's reasoning. Summaries or secondary magazines. The content of the primary magazines is collected, in the form of summaries.

Magazines of scientific or technological progress. Summary reports of the main research programs contained in the primary journals are published. 
On the other hand Robert A. Day (1998) divides scientific journals into three levels, first level, are edited with the backing of societies recognized by the international community. Generally they have the approvals of their partners; the second level magazines, are sponsored by major transnational companies such as Elservier, Pergamon Press, among others; its cost are higher which limits its circulation, and Third Level Magazines are published by public institutions, such as universities museums, hospitals, its greatest limitation, depends on the administrative logic of the institutions, such as budgets, changes of officials, which affects the periodicity and its diffusion.

In this same sense Cardinali (2010) states that the quality of the journals is defined by the compliance with a set of editorial guidelines, presentation, content management to ensure the scientific quality of the articles published and therefore to its prestige. Each journal has its own guidelines that seek to raise its scientific level and therefore its impact.

For the researcher, one of the purposes to be considered is the influence of the publications that are made in a scientific journal, for which there are four indicators that help to know to what extend they have impact publications such as: Usage statistics, Subscriptions, Visibility and Factor of impact. Of these, the most analyzed indicator for its formalism and implications is the Impact Factor. (Falgueras \& Alcaraz, 2006)

Then the impact factor defined by Eugene Garfield around 1960 and published by Thomson Reuters ISI (the new name of ISI), is the most widely accepted indicator by the scientific community to evaluate the contents of a scientific journal. This index measures the impact a magazine has had on the scientific community. The coefficient is derived from the division of the number of articles published during two years in a journal and the number of citations that this publication has received in the same period.

\begin{tabular}{l|l}
725 & Vol. 3, núm. mon., agosto, 2017, pp. 714-733 \\
Nancy E. Tapia-Gaibor; José M. Lalama-A
\end{tabular} Nancy E. Tapia-Gaibor; José M. Lalama-Aguirre; Santiago O. Sánchez-Andrade; Chistian R. TapiaGaibor; Vanessa P. Quishpe-Morocho; Patricia G. López-Fraga 
These measurement analyzes the methodology, quantitative enumeration to measure published articles, and the factor of citations and the impact factor, by their inter- disciplinary publications, philosophy of science and linguistics, maintaining a close relation with the perspective of positivism (Raan, 1997)

Now we can see that although the output of scientific production can be measured through its number of publications (bibliometrics), it is also possible to register its entries through the identification of investment in research and development $(I+D)$ that pulls a country towards research and scientific production.(Vargas, 2007)

As there are tools to evaluate scientific journals, there is also hierarchy and is precisely the impact factor: an indicator of the number of citations that receive on average the work published in a certain magazine "(Gómez and Bordons, 1996 :) . The indexes are published through the Institute for Scientific Information (ISI); Science Citation Index (SCI); Social Science Citation Index (SSCI); Web of Science (WoS).

For its part, the Organization for Economic Cooperation and Development (OECD) defines bibliometrics as the discipline that measures and analyzes the production of science in the form of articles, publications, subpoenas, patents, etc. is to identify the laws and regulations of scientific activity, for alternatives in scientific policy and its management (Callon, 1993)

Sciencemetric is characterized by its interdisciplinary and relationship with the philosophy of science and linguistics. (Raan, 1997)

The University as a privileged space of scientific production under the context of internationalization of knowledge and under the premise that science is recognized as a public good, 
arises from bibliometrics and computer science as a complementary methods for the measurement of science and technology .The Organization for Economic Cooperation and Development (OECD) defines methodologies and indicators for the measurement of inputs and outputs of scientific production and purposes: strengthening research management structures and processes, distributing resources according to priorities. (Vargas, 2007)

\section{The Scientific Communities}

The scientific communities allow to generate, to argue and to validate the knowledge, to obtain its legitimacy, the contributions are subject to the review and analysis of the discipline. This implies making the results of the research public, and the acceptance and recognition of such results are also public, for example, through citations, (Aguado, Rogel, Garduño, Oropeza, Zúñiga, 2008). It is in this logic, the Technical university of Cotopaxi, have created clusters of researchers to generate knowledge.

They are a research group and networks that, through ICT, have crossed borders and have contributed to the generation of knowledge by consolidating the so-called networks of excellence. However, there are other alternatives for the diffusion of knowledge. Latindex is constituted at regional level with passport to be viewed and footing for new records in data basis and hemerographic indixes.

That is why it is the importance of internationalizing knowledge through scientific production in Scientific Journals, for this is the support of research groups and network to place themselves in the international scientific market, always with topics relevant to the general interest and context.

\footnotetext{
\begin{tabular}{l|l}
727 & Vol. 3, núm. mon., agosto, 2017, pp. 714-733 \\
Nancy E. Tapia-Gaibor; José M. Lalama-Aguirre; Santiago O. Sánchez-Andrade; Chistian R. Tapia-
\end{tabular} Gaibor; Vanessa P. Quishpe-Morocho; Patricia G. López-Fraga
} 
To make visible the scientific publishing production of the region, understood as the increase in its consultation and citation; that is, that the knowledge generated be positioned in the international context. To achieve this, the open access movement provides the fundamental elements. Open access was formalized in the years 2002 and 2003 with the declarations of Budapest, Bethesda and Berlin, after which their main characteristics were established:

Authors guarantee the free access to the scientific texts through the Internet, for their reading, printing, emptying and distribution, without legal, technical or financial impediments, respecting the existing copyright laws. Some of the key benefits of open access are as follows: • It increases the visibility and impact of specialized publications. It increases the citation of the scientific articles that are seen. - Reduce costs and make editorial production more efficient. (Aguado, Rogel, Garduño, Oropeza, Zúñiga, 2008)

The study of (Ríos \& Herrero, 2005) states that in the 80's and 90's there were a boom in scientific production. According to these authors the low level of production is due to the little investment. The production is focused on the largest cities and corresponds more to the areas of medicine. Brazil and Mexico are the countries that lead the path according to the biometric analysis. In other countries, there is a limited scientific production. Finally, they consider that political decisions are very important in regional results.

There is an asymmetric distribution of knowledge in the world and it is not reaching all equitably; this asymmetry in consumption consequently also generates an asymmetry in production. If you want to access the information contained in the main journals of each discipline, you must have sufficient resources to acquire them; the same thing if one wants to publish in them, conditions that many Ibero-American institutions do not possess. 
There are scientific journals that serve as channels of communication and dissemination; however, not all of them have the same prestige and influence in the scientific community. The most relevant are: Anglo-Saxon, American and Canadian (Plaza and Bordons, 2006)

Thus, in a globalized world, knowledge also has its space, through databases, scientific journals, catalogs, repositories, which are part of this dynamic and which correspond to the internationalization of scientific diffusion. The Technical University of Cotopaxi, as an institution of higher education generates scientific production and access with 31 of 33 criterias in the year 2015 to the Latindex Catalog for its international visibility.

The holistic understanding of the role of the teacher constitutes a fundamental element for its praxis, as well as the establishment of its competences between the fusion of the formative research, starting from a teaching model that goes beyond the traditional model of transmission and skills and motivations that covers research reading, writing, analysis, criticism, self-criticism, creativity, among others, thus empowering the researcher to contribute and generate knowledge, and finally, the socialization of scientific production results.

But for this, we must also consider copyright which represents a set of norms and principles that regulate the moral and patrimonial rights that the law grants authors for the sole fact of the creation of a literary, artistic or scientific work. (Burgos Aguilar, 2010)

The trend in society of knowledge is scientific production; publications in international journals, the most used media; ICT are the tools by which diffusion expands rapidly, in the last decades there were an overflowing information; nevertheless the electronic catalogs are the means that guarantee scientific collection by its publishing Committees with peer review.

\footnotetext{
729 Vol. 3, núm. mon., agosto, 2017, pp. 714-733 Nancy E. Tapia-Gaibor; José M. Lalama-Aguirre; Santiago O. Sánchez-Andrade; Chistian R. TapiaGaibor; Vanessa P. Quishpe-Morocho; Patricia G. López-Fraga
} 
Even the World Bank has defined access to information and communication technologies (ICT) as one of the four basis to measure their progress in knowledge and economy (World Bank Institute, 2008)

In recent years there have emerged several types of applications and platforms that help scientists with their work, there are tools for the tracking and management of information, it has been called Science 2.0, and can be defined by analogy with the definition of web 2 .0. Some of them include:

- http://scienceblogs.com/

- $\quad$ http://weblogs.madrimasd.ord/

- http://network.nature.com/.com/

- http://plos.org/cms/blog/

- http://www.plos.org/

- www.postgenomic.com/

- $\quad$ http://blogs.bmj

Within the academic progress we also have reference managers and social labeling sites, whose purpose is to guide the process of writing scientific articles, as a direct consequence of the transfer of scientific production methods to the digital environment. The characteristics of these products is to import, extract references, collaborative and to be flexible. (Cabezas Clavijo, Torres Salinas, \& Delgado, 2009)

ICT act as a catalyst for knowledge management, considering them elements that with their proper use are able to react to the other factors involved in the KM, accelerate the processes of the 
same and allow the creation of favorable contexts for the development and expansion of knowledge. (Pérez, 2007)

These office products have helped the management of bibliographic references. Companies like Elservier, has integrated the product 2collab, among other products, into the Scopus data base free of charge; we ran Zotero reference manager or within social networks Mendeley (Cabezas, 2009)

One of the latest innovations in the scientific community is the use of audio clips (podcast) as a new form of scientific communication, among them we have interviews with scientists, documentaries, conferences, experiments and scientific articles that must also go through the process of peer review. (Cabezas et al, 2009)

\section{Bibliography:}

Aguado, Rogel, Garduño, Oropeza, Zúñiga. (2008). Redalyc: Una alternativa a las asimetrías en la distribución del conocimiento científico. Ciencia, Docencia y Tecnología $N^{\circ} 37$.

Albornoz, M. (2001). OEI. Revista Iberoamericana de Ciencia, Tecnología y Sociedad. Obtenido de http://www.oei.es/revistactsi/numero1/albornoz.htm

Anisleiby Fernández Hernández, S. C. (2009). Producción Científica sobre ontologías en el Web of Science, 1998-2007.

Burgos Aguilar, J. V. (2010). Distribución de conocimiento y acceso libre a la información con recursos educativos abiertos (REA).La educ@ción.

Cabezas Clavijo, A., Torres Salinas, D., \& Delgado, E. (2009). Ciencia 2.0: Catálogo de herramientas e implicaciones para la actividad investigadora.

Callon, M. (1993). Presses UniversColection. La Scienciometrie.

Capurro, R. (2015). Qué es una revista científica? Informatio.

Cetto, A. M. (1998). Ciencia y producción científica en América Latina. El proyecto Latíndex. Editorial. 
CES, CIFI, UTC, 2016 - 2017, Latacunga

Dávila. (2006). Preservación del Patrimonio Intelectual Académico. Interciencia.

Escobar, B., García, E., \& Larrán, M. (2014). Factores que influyen sobre la producción científica en Contabilidad en España: la opinión de los profesores universitarios de Contabilidad (II parte). Revista Española de Documentación Científica, 1 - 15.

Falgueras , E. A., \& Alcaraz, L. R. (2006). Revistas Científicas digitales: características e indicadores . Revista de Universidad y Sociedad del Conocimiento .

Fernandez, M., Gómez, I., \& Sebatián, J. (1998). La cooperación científica de los países de América Latina a través de indicadores bibliométricos. Interciencia, 328 - 337.

Feyen, J., \& Vásquez, R. (2010). La clasificación de las unievrsidades como herramienta de gestión universitaria. Mashkana, 3 - 16.

Latidex. (2016). Latindex hoy. Recuperado el 26 de 06 de 2016, de http://www.latindex.org/latindex/hoy

Lombardo, T., De dos Soler, C., \& Aguilera, E. (2013). Consideraciones en torno al problema de las publicaciones científicas de los profesionales de la salud.

Macías, C. . (2001). bibliometric and webometric analysis of healt system reforms in Latin América and the Caribbean. Scienciometrics.

Miguel, S. (2011). Revistas y producción científica de América Latina y el Caribe: su visibilidad en SciELO, RedALyC, y. Revista Interamericana de Bibliotecología, 187 - 199.

Morales Melvi, M. M. (1997). La informetria y las fuentes personales e institucionales: su importancia en relación con la información de inteligencia. Biblat.

Peña, V. A. (s.f). Univ ersidad y la producción cienífica.

Pérez, D. (2007). Tecnologías de la información para la gestión del conocimiento . Intangible capital, 16.

Piedra , Martínez. (2007). Producción Científica. Ciencias de la información.

Quintanilla, A. (2008). La ciencia y su producción de conocimiento en América Latina. SciELO, 83 $-91$.

Raan, V. (1997). Scienciometrics: State -of-the art. Scientometrics.

Ríos, C., \& Herrero, V. (2005). La producción científica latinoamericana y la ciencia mundial: Una revisión bibliográfica. Revista Interamericana de Bibliotecología: 43 - 61.

Spinak. (1996). Diccionario enciclopédico de bibliometría, cienciometría e informería. . Caracas. 
Toledo, M. L. (1 de abril de 2012). infolatam. Recuperado el 25 de junio de 2016, de infolatam: http://www.infolatam.com/2012/04/01/investigacion-desarrollo-y-rankings-cientificos-paraamerica-latina-universidades-top/

Vargas, D. C. (2007). Medir la producción científica de los investigadores uiversitarios: la bibiometría y sus límites. Revista de la Educción Superior.

Vera, P., López, W., Lillo, S., \& Silva, L. (2011). La producción científica en psicología latinoamericana: Un análisis de la investigación por países. Revista Latinoamericana de Psicología, 95 - 103.

Yelina Piedra, A. M. (1997). Producción Científica. Ciencias de la Información. 38(3): 33-38. 